\title{
Standards of Transport Services - Central Strategy versus Regional Priorities - Workshop Report of the 9th Telč Seminar
}

\author{
Martin Kvizda, ${ }^{1}$ Tomáš Nigrin, ${ }^{2}$ Daniel Seidenglanz, ${ }^{3}$ and Zdeněk \\ Tomeš $^{4}$
}

On two typical autumn days, November 6 and 7, 2014, the Department of Economics at the Faculty of Economics and Administration of the Masaryk University in Brno, in cooperation with the Institute of International Studies of the Faculty of Social Sciences of the Charles University in Prague (both located in the Czech Republic), organized the $9^{\text {th }}$ Annual Telč Seminar, which took place in the University Centre of the Masaryk University in Telč. The main topic of the seminar, supported by a grant from the Technology Agency of the Czech Republic, was Standards of Transport Services: Central Strategy versus Regional Priorities.

The goal of the seminar was to define the standards of transport services and, especially, to discuss the interplay of central strategy and regional priorities. The seminar was opened by Jan Hrabáček and Tomáš Pospíšil (both ČD - Czech Railways, Inc.), who presented Standards of Transport Services from the Perspective of a National Carrier; this contribution provoked an extensive discussion that focused mainly on the issue of finding ways to fund new carriages. Then, Antonín Peltrám (Masaryk University Brno) gave a talk titled Standards of Transport Services: Central Strategies vs. Regional Priorities in Conditions of Market Economy with Privatisation (Peltrám 2014). The morning portion of the seminar was closed by Ondřej Krčál (Masaryk University Brno), who presented on A Simulative Model Of Long-Distance Passenger Railway Transport. The afternoon focused on a more geographical conception of transport services standards and was started by a presentation from Rostislav Farkaš (Charles University Prague), who looked into Standards of Transport Services: Geographical Aspects. The discussion that ensued was followed by Ján Ponický (University of Žilina) and his survey of

\footnotetext{
${ }^{1}$ Masaryk University, Faculty of Economics and Administration, Department of Economics, Lipová 41a Brno602 00, kvizda@econ.muni.cz.

${ }^{2}$ Charles University in Prague, Faculty of Social Sciences, Institute of International Studies, U Kř́že 8, 15000 Praha 5; nigrin@ fsv.cuni.cz.

${ }^{3}$ Masaryk University, Faculty of Science, Department of Geography, Kotlářská 2, 61137 Brno, seidenglanz@geogr.muni.cz.

${ }^{4}$ Masaryk University, Faculty of Economics and Administration, Department of Economics, Lipová 41a Brno 602 00, Tomes@econ.muni.cz.
}

(C) 2015 by the authors; licensee Review of Economic Perspectives / Národohospodárský obzor, Masaryk University, Faculty of Economics and Administration, Brno, Czech Republic. This article is an open access article distributed under the terms and conditions of the Creative Commons Attribution 3.0 license, Attribution - Non Commercial - No Derivatives. 
the Bratislava Integrated Transport System (Ponický et al. 2014). Next, Tomáš Nigrin (Charles University Prague) and Jiří Dujka (Masaryk University Brno) presented a detailed comparative study, A comparison of transport services principles in Germany and Austria (Nigrin and Dujka 2014). Daniel Seidenglanz (Masaryk University Brno) picked up the threads of this comparison, presenting Regional Railway Transport: Differences between the Czech Republic, Germany, and Austria. The evening discussion session dealt with more strategic issues and was opened by Jiří Pohl (Siemens Ltd. Prague), who elicited an extensive discussion titled The Potential of Modern Railway for growth of Transport Services Quality (Pohl 2014). Lumír Pečený (University of Žilina) then introduced the attendees to The Quality Criteria of Regional Passenger Railway Transport in Slovakia (Pečený et al. 2014), and Václav Rederer (Masaryk University Brno) closed a long day full of discussion in a summary talk titled Public transport in the Czech Republic: The Milestones and the Influence of Common Transport Policies in the EU (Rederer 2014). In following discussions, the workshop participants reached the conclusion that the transparent identification of standards for public transport services is crucial for the liberalization of and tendering for effective public transport service.

The second part of the seminar consisted of a panel discussion aimed at defining standards for regional transport moderated by Martin Kvizda and Daniel Seidenglanz (both Masaryk University Brno) and featured Miroslav Marada (Charles University Prague; focusing on transport geography), Petr Pšenička (SŽDC - Railway Infrastructure Administration), Lumír Pečený (University of Žilina; focusing on transport engineering), and Tomáš Pospíšil (ČD - Czech Railways Inc.). As a follow-up to this discussion, several basic issues were raised, which gave rise to a lively discussion in which not only panel speakers but also other participants in the seminar engaged around the following questions:

- Which type of transport needs should be served by subsidized regional transport?

- What should be the spatial definition of regional transport?

- What is the optimum temporal standard for regional transport?

- What does a suitable group ordering regional transport look like?

- How should regional transport be coordinated with its long-distance counterpart?

Several important conclusions emerged from the discussion. As society grows increasingly polarized (e.g., urban agglomerations vs. rural settings), the integrative role played by transport is vitally important. Society is developing along two tracks in the Czech Republic. On the one hand, mutual relations inside metropolitan regions (i.e., polynodal structures), where the formation of integrated transport systems can be expected, have been growing more intense; on the other hand, there are rural regions with regional transport (i.e., mononodal structures), the connections of which are often inconvenient. The importance of regional transport lies not only in service within the region but also in the functional connection of the given region with economic and social centres outside the region. Residential systems do not solely comprise large cities; economic development may depend on a rather large number of relatively strong microregional centres. These centres, too, should therefore be functionally interconnected with their economic and social counterparts. Active policies aimed at supporting rural regions 
should strive to support regional centres, including those that may be seen as relatively weak, but which still play necessary social and economic roles in the microregion. This support should include a functional system of regional public transport services, where the public sphere should be obliged at least to provide public transport to activities deemed to be compulsory by the state, such as school attendance, commuting in order to take care of state-related business, etc.

From an economic perspective, railway transport is only effective when there is a transportation stream of approx. 900 people in one direction; when the figure is lower, alternative modes of transport are more efficient. Nonetheless, overemphasizing the provision of rail service to as many settlements located in the vicinity of the line as possibly may prove counterproductive, too, as building new stops (making a train's stops denser) results in slower connections, difficulties in coordinating travel times across the system, and suboptimal use of investments in track modernisation that increase track speed. An optimum system of regional public transport should therefore be based on a backbone of railway connections supplemented by linking bus connections. It is appropriate to provide basic transport services by alternative means in sparsely inhabited regions; this includes subsidized taxi services and individual car transport. The quality of such services - especially in terms of connection frequency, vehicle facilities, and auxiliary services - must be adjusted to the needs of the transport stream. Maintaining excessively high standards on sparsely used connections would be a waste of public funds.

The fact that locations designed for housing and economic activity have emerged on the peripheries of population centres and in the open countryside around motorway junctions, etc., is a distinctive phenomenon of the last decade in particular. These locations are built without any premeditated vision for the long-term development of the region or any meaningful relation to urbanisation. These built-up residential and industrial areas, which emerge more or less without any advance planning, have given rise to new, ad hoc demands on regional transport service and have impeded the efficient use of public funds designated for transport infrastructure. The public sphere has the power to influence the spatial arrangement of economic activities in relation to where transport services are feasible and maximally efficient. Moreover, the state is politically responsible for those decisions. From this perspective, it can be said that the long-run importance of regional planning has been underestimated in the Czech Republic. In Austria, for example, newly built shopping centres and industrial zones are obliged to contribute to their respective municipalities and communities for public transport.

Due to the constitutional organisation of the Czech Republic, responsibility for regional transport is transferred to the regional authorities. Though the creation of regions in the Czech Republic may originally have been an administrative act that often did not reflect the natural economic and cultural inclinations of certain regions (especially those located on the national borders), it is now clear that a more convenient system of management and organisation for regional transport will not be possible. Integrated transport systems overlapping into neighbouring regions or the non-existence of regional connections that would reach over the regional border, these are questions that are bound to be dealt with individually. Given their urgency, they should not be dealt with by a blanket administrative decision. 
An overarching vision for public transport in the Czech Republic is a key prerequisite for successful regional transport. As far as regional self-governments and municipalities operating broad networks of public transport are concerned, the Ministry of Transport of the Czech Republic plays an irreplaceable role as coordinator and methodologist. All presentations from the seminar and much more information are available at wWw.transporteconomics.eu.

\section{References}

NIGRIN, T., DUJKA, J. (2014) A comparison of transport services principles in Germany and Austria. In M. Kvizda - Z. Tomeš (eds.) Standards of Public Transport: Central Strategy vs. Regional Priorities. Brno: Masaryk University, p. 14-38

PEČENÝ, L., GAŠPARÍK, J., DOLINAYOVÁ, A. (2014) The quality criteria of regional passenger railway transport in Slovakia. In M. Kvizda - Z. Tomeš (eds.) Standards of Public Transport: Central Strategy vs. Regional Priorities. Brno: Masaryk University, p. 39-50

PELTRÁM, A. (2014) Standards of transport services - central strategies vs. regional priorities in conditions of market economy with privatisation. In M. Kvizda $-Z$. Tomeš (eds.) Standards of Public Transport: Central Strategy vs. Regional Priorities. Brno: Masaryk University, p. 51-57

POHL, J. (2014) The potential of modern railway for growth of transport services quality. In M. Kvizda - Z. Tomeš (eds.) Standards of Public Transport: Central Strategy vs. Regional Priorities. Brno: Masaryk University, p. 58-67

PONICKÝ, J., KENDRA, M., L'UPTÁK, V. (2014) Bratislava Integrated Transport System. In M. Kvizda - Z. Tomeš (eds.) Standards of Public Transport: Central Strategy vs. Regional Priorities. Brno: Masaryk University, p. 68-78

REDERER, V. (2014) Public transport in the Czech Republic - the milestones and the influence of common transport policies in the EU. In M. Kvizda - Z. Tomeš (eds.) Standards of Public Transport: Central Strategy vs. Regional Priorities. Brno: Masaryk University, p. 79-93. 